\title{
Climate changes at the LGM-Holocene in the south of East Siberia (Russia) inferred from lake diatom records
}

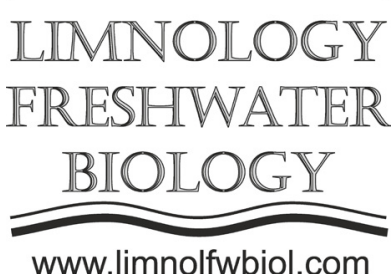

\author{
Vorobyeva S.S.*, Zheleznyakova T.O., Fedotov A.P. \\ Limnological Institute of the Siberian Branch of RAS, Ulan-Batorskaya st., 3, Irkutsk, 664033, Russia
}

\begin{abstract}
In this study, we analysed a $54 \mathrm{~cm}$ long sediment record from small lake located closely to Lake Baikal for subfossil diatom to provide an improved reconstruction of the environmental changes in the area for the past $12.4 \mathrm{ka}$. Significant changes in diatom records occurred at 10 and 4.8-4.2 ca. ka BP. The pattern of studied diatom records was close to ones from Lakes Baikal and Khubsugul.
\end{abstract}

Keywords: diatoms, reconstruction, lake, bottom sediments, East Siberia

\section{Introduction}

Diatom records are a good proxy of paleoclimate changes. Diatoms are well-known to depend on water temperature, duration of open and close water, insolation and supply of nutrients into the water. Main focus in this study was on climate changes occurred in the south part of East Siberia at transition from glacial to warm condition and the Middle Holocene.

\section{Material and Methods}

Lake Okunevoe is located in the south part of East Siberia (Russia) closely to Lake Baikal. Lake Okunevoe $\left(51^{\circ} 26^{\prime} \mathrm{N}, 104^{\circ} 50^{\prime} \mathrm{E}\right)$ is a small freshwater lake located at $510 \mathrm{~m}$ above sea level, with an area of approximately $0.02 \mathrm{~km}^{2}$.

In 2017, a sediment core was taken from the central part of Lake Okunevoe (54 cm long) using a Uwitec Corer sampler. The water depth was $6 \mathrm{~m}$ at the core sampling site.

The cores were sampled with $1 \mathrm{~cm}$ intervals. Diatom frustules (from 400 to 800 frustules per sample) were identified using keys, atlases and a reference collection (Round et al., 1990; Glezer et al., 1992).

The total radiocarbon content in the graphitized samples was quantified by AMS engineered at Budker Institute of Nuclear Physics (Novosibirsk, Russia). Calendar date was evaluated from the radiocarbon one by CalPal ver.1.5.

\section{Results and Discussion}

Age estimation shows that the sediment records began to form from ca. 12.5 cal. ka BP. Twenty four diatom taxa were found in the sediment records. Amount of plankton diatoms changed from 0.01 to
$15.8 \times 10^{6}$ frustules/g. Aulacoseira pfaffiana (Reinsch) Krammer (up to $15.8 \times 10^{6} \mathrm{fr} . / \mathrm{g}$ ) and Tabellaria flocculosa (Roth) Kützing (до $0.54 \times 10^{6} \mathrm{fr} . / \mathrm{g}$ ) were dominant in plankton assemblage. Aulacoseira sp., A. subarctica (O. Müller) Haworth, Cyclotella sp. and C. minuta (Skv.) Antipova, Stephanodiscus meyeri (Genkal et Popovsk.) were in minor amounts.

Aulacoseira pfaffiana and Tabellaria flocculosa are cold freshwater cosmopolitans that prefer reduced $\mathrm{pH}$ and mineralization water. Benthos diatoms are presented by 17 taxa with amount from 0.28 to $10.13 \times 10^{6} \mathrm{fr} . / \mathrm{g}$. Neidium (up to $6.2 \times 10^{6} \mathrm{fr} . / \mathrm{g}$ ) and Frustulia (up to $5.7 \times 10^{6} \mathrm{fr} . / \mathrm{g}$ ) were dominant. The ratio of Eunotia was up to $29 \%$ in some layers. Cysts of Chrysophyta were 0.6 to $35 \times 10^{6}$ cysts $/ g$.

Amount of plankton diatoms began increasing from ca. 11 cal. ka. BP and its maximums occurred at 10 and 4.8-4.2 ca. ka BP, while it was one maximum of benthic diatoms at 4.8-4.2 ca. ka BP (Fig. 1). In the largest Lakes Baikal and Khubsugul (Northern Mongolia) the first diatom maximum also occurred at 10 ca. ka BP (Fig. 1). It is notable that plankton diatoms occupied the first Lake Okunevoe. It likely evidences that the increasing of lake level rapidly happened after the Last Glacial Maximum (LGM). Thus, it can assume that the regional increasing of moisture was very strong and fast at the transition from the LGM to Holocene.

Regional climate changes reflected in diatoms records also were very significant, when changes in diatom assemblages were occurred not only in small Lake Okunevoe also in Lakes Baikal and Khubsugul (Fig. 1). Thus, diatoms strongly reduced in Lake Baikal and Khubsugul at ca.5 ka BP, and was increase in benthic diatom in Lake Okunevoe when Cymbella $s p$. was replaced by Neidium. In Lake Khubsugul Cyclotella bodanica disappeared from diatom records after $c a .5 \mathrm{ka}$ BP (Fedotov et al., 2004). 


\section{Conclusions}

We studied diatom record from small Lake Okunevoe is closely located to the Lake Baikal. The diatom records formed for the past $12.4 \mathrm{ka}$. The distribution of the diatom record closely related with ones for Lakes Baikal and Khubsugul. There were two period in to increase of amount of diatoms at 10 and 4.8-4.2 ca. ka BP.

\section{Acknowledgements}

This study was supported by basic funding No. 0345-2016-0006 (AAAA-A16-116122110063-0), RFBR-17-29-05016 (financial support of laboratory materials and equipment). We thank V.E. Chernikh for core sampling, E.V. Parkhomchuk, P.N. Kalinkin and S.A. Rastigeev for AMS dating.

\section{References}

Fedotov A.P., Chebykin E.P., Semenov M.Yu. et al. 2004. Changes in the volume and salinity of Lake Khubsugul (Mongolia) in response to global climate changes in the upper Pleistocene and the Holocene. Paleogeography, Paleoclimatology, Paleoecology 209(1-4): 245-257.

Gleser S.I., Makarova A.I., Moiseeva A.I., Nikolaev V.A. (eds). 1992. The diatoms of the USSR (fossil and recent). II (2). S.-Peterbourg: Nauka. (in Russian).

Round F.E., Crawford R.M. and Mann D.G. 1990. The Diatoms. Biology and morphology of the genera. Cambrige: Cambrige University Press.

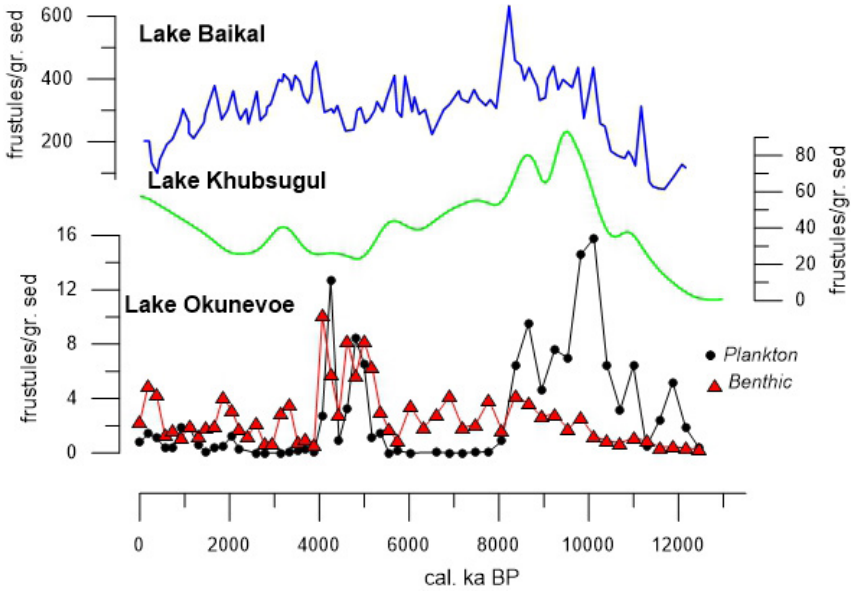

Fig.1. Distribution of diatoms in studied lake (Okonevoe), Lakes Baikal and Khubsugul (Northern Mongolia) 